UNDERGRADUATE RESEARCH IN NATURAL AND CLINICAL SCIENCE AND TECHNOLOGY (URNCST) JOURNAL Read more URNCST Journal articles and submit your own today at: https://www.urncst.com

\title{
Pleiotropic Roles of Cytokines in HIV-1 Pathogenesis and Control: A Literature Review
}

Homaira Hamidzada, HBSc [1], Christina Guzzo, PhD [1,2]*

[1] Department of Biological Sciences, University of Toronto Scarborough, Toronto, Ontario, Canada M1C 1A4

[2] Department of Cell \& Systems Biology, University of Toronto, Toronto, Ontario, Canada M5S 3G5

*Corresponding Author: christina.guzzo@utoronto.ca

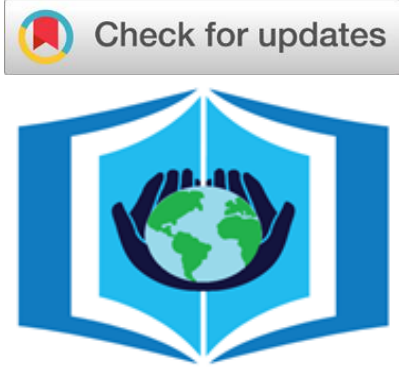

URNCST Journal "Research in Earnest"

\begin{abstract}
Introduction: Human Immunodeficiency Virus (HIV) is a retrovirus that infects human immune cells, primarily CD4 ${ }^{+} \mathrm{T}$ cells and macrophages. During HIV disease progression, infected individuals have declining $\mathrm{CD}^{+}{ }^{+} \mathrm{T}_{\text {cell }}$ counts and increasing HIV RNA, indicative of virus replication. Numerous studies have identified important roles for cytokines in immune responses during the course of HIV infection. Cytokines are small molecular weight proteins that communicate signals between a broad range of cells in the immune system. This review aims to highlight a key subset of cytokines that bear potential as targets for the prevention and treatment of HIV infection.

Methods: We conducted a literature review categorizing pertinent cytokines on the basis of four criteria: correlations with HIV replication, impact on host innate immune cells, characteristic expression in elite controllers, and therapeutic applications. Results: We identified several cytokines in the interleukin (IL) family and the C-C and C-X-C chemokine families with important roles in HIV-1 control. Indeed, the expression of many cytokines was correlated with reduced HIV-1 replication (e.g. IL-21, IL-32, IL-27). Several cytokines directly impact cells of the innate immune system in their HIV-1 control mechanisms. Among many, IL-7 and IL-15 are able to enhance natural killer cell function, while IL-27 enhances macrophage resistance to HIV infection. Elite controllers, individuals who have suppressed HIV-1 replication and preserved CD4 ${ }^{+} \mathrm{T}$ cell levels without exogenous antiviral drug treatment, express a uniquely characteristic array of chemokines. Namely, CCL14, CCL27, CCL21, XCL1 and CXCL12 are upregulated in elite controllers compared to non-controllers. Finally, considering the diversity and pleiotropic roles of cytokines during HIV-1 infection, many bear potential for inclusion in therapeutic designs .

Conclusion: Herein, we have highlighted the antiviral roles of several cytokines, demonstrating that many cytokines are key regulators of HIV replication. This work provides a focus for future research aiming to better understand HIV pathogenesis and informs novel preventative and therapeutic designs.
\end{abstract}

Keywords: HIV infection; cytokines; chemokines; HIV-1 control; elite controllers; antivirals

\section{Introduction}

The World Health Organization reports that as of 2017, a total of 36.9 million individuals were living with the Human Immunodeficiency Virus (HIV) [1]. In 2017 alone, nearly one million lives were claimed globally due to HIV infection [1]. Given the ongoing and immense global impact of HIV infection, studies of HIV pathogenesis are critically needed to inform new therapeutic mechanisms that can help to curb the HIV pandemic.

HIV is a lentivirus (a subgroup of retroviruses) that infects cells of the immune system, primarily $\mathrm{CD} 4^{+}$ T lymphocytes and macrophages [2]. HIV can be categorized as either HIV-1 or HIV-2, where HIV-1 infection is more prevalent, results in higher viral loads, and is more transmissible [3]. The virus consists of a rigid capsid formed by several thousand copies of p24 Gag, the most abundant viral protein [2]. Within the capsid there exists two identical copies of a positive-sense, single-stranded RNA genome (nine genes encoded), along with viral enzymes important for virus integration and replication: reverse transcriptase, protease and integrase [2]. The outermost, external coat of the virus is termed the viral envelope, composed of a hostderived lipid bilayer surrounding the viral capsid [2]. The key viral glycoprotein (gp) embedded within this envelope is a trimeric spike of gp120/gp41, with gp120 visible at the outermost spike, and gp41 concealed as a transmembrane protein important in fusion [4]. Importantly, gp120/gp41 is responsible for the attachment of the virus to the host cell receptors and subsequent fusion of viral and host membranes [5]. In short, gp120 first binds to the CD4 receptor on CD4 ${ }^{+}$ $\mathrm{T}$ cells (or macrophages), subsequently followed by a binding event to a co-receptor, one of the chemokine receptors, C-C chemokine receptor 5 (CCR5) or C-X-C chemokine receptor 4 (CXCR4) [5]. HIV viruses that use the 
UNDERGRADUATE RESEARCH IN NATURAL AND CLINICAL SCIENCE AND TECHNOLOGY (URNCST) JOURNAL Read more URNCST Journal articles and submit your own today at: https://www.urncst.com

CCR5 co-receptor are termed R5-tropic, while those that use the CXCR4 co-receptor are termed X4-tropic [6]. Upon binding to the co-receptor, conformational changes in gp120/gp41 occur such that the membrane of the virus and host cells fuse, releasing the viral capsid into the host cell cytoplasm [5]. The retrovirus is then reverse-transcribed by the viral reverse transcriptase and subsequently integrated into the host genome [7]. It can then be transcribed and translated into viral proteins within host cells (using host cell machinery) and subsequently assembled into de novo virus particles [7]. Ultimately this leads to the death of $\mathrm{CD}^{+}{ }^{+} \mathrm{T}$ cells, resulting in declining $\mathrm{CD}^{+}{ }^{+} \mathrm{T}$ cell counts over time, leaving the infected individual deficient of these essential immune cells [8]. Simultaneously, as $\mathrm{CD}^{+}{ }^{+} \mathrm{T}$ cell levels drop circulating HIV-1 RNA (plasma viral load) rises.

Central to HIV-1 pathogenesis and disease is the host immune system, which is comprised of an array of unique immune cells, such as $\mathrm{CD}^{+} \mathrm{T}$ cells, and immune proteins, such as cytokines. This review explores the roles of various cytokines in HIV-1 infection, while also highlighting the therapeutic potential of exploiting cytokine activities for use in the control of (i.e. blockade of) HIV-1 replication. Cytokines are small molecular weight proteins that communicate messages between cells of the immune system in order to elicit a response or effect [9]. There are several antiviral cytokines that play an integral role in HIV-1 infection. Antiviral activities of cytokines can be elicited through direct antiviral activity of a particular cytokine, but can also be elicited indirectly, through suppression of other cytokines that act to enhance HIV replication [10]. Within the interleukin (IL) family of cytokines, several have been established to play a critical role in inhibiting HIV-1 replication (IL-21, IL-27, IL-32) [11-14]. Many cytokines perform their antiviral functions by direct activity on cells of the innate immune system including macrophages and natural killer (NK) cells [15-17]. Importantly, elite controllers (ECs), individuals who can naturally fight HIV-1 infection without therapeutic intervention, have an their interesting 'signature' of cytokine expression supporting natural ability to control infection [18]. Given the unique groups of cytokines with diverse functions, novel therapeutic interventions including cytokines are a viable option that could be explored. Despite this potential, a critical first step is to fully characterize the pleiotropic roles of cytokines and chemokines in the context of HIV infection, a major aim of this review article.

\section{Methods}

We conducted a literature review categorizing pertinent cytokines on the basis of four criteria: correlations with HIV-1 replication, impact on host innate immune cells, characteristic expression in elite controllers, and therapeutic applications.

\section{Results \\ Cytokine Correlates in HIV-1 Infection}

This section considers cytokines, either antiviral or not, that have been shown to be involved in HIV-1 pathogenesis and control of replication. IL-21, IL-32 and IL-27 are antiviral cytokines that when present at high levels, contribute to HIV-1 control (decreased virus replication) [11-14]. Firstly, Adoro et al. demonstrated that the cytokine IL-21 promotes upregulation of microRNA-29 in $\mathrm{CD}^{+} \mathrm{T}$ cells, resulting in the suppression of $\mathrm{HIV}-1$ replication [11]. Using a humanized mouse model of HIV infection, it was demonstrated that exogenous treatment with IL-21 reduced HIV-1 replication and viral load [11].

Complimentary studies have demonstrated an antiviral role for IL-32 in HIV-1 infection. Using peripheral blood mononuclear cells (PBMCs) from HIV-1 infected individuals, it was demonstrated that upon knocking down IL-32 via small interfering RNA (siRNA), HIV-1 replication increases (p24 levels elevated), demonstrating that IL-32 inhibits HIV-1 replication [19]. Nold et al. performed a similar study confirming the anti-HIV activity of IL-32, while also showing that IL-32 is involved in the upregulation of pro-inflammatory cytokines IL-6, interferon-gamma (IFN- $\gamma$ ) and tumor necrosis factor-alpha (TNF- $\alpha$ ) [12]. In the setting of IL-32 depletion, the NF- $\kappa$ B and AP-1 transcription factors showed less DNA binding activity, resulting in decreased expression of IFN- $\gamma$ [12], an antiviral cytokine involved in HIV-1 control [20]. Interestingly, upon addition of exogenous IFN- $\gamma$ to the HIV-infected PBMCs with inhibited IL-32 expression, HIV-1 replication decreased [12]. Thus, this study shows that the antiviral role of IL-32 is dependent, in part, on NF- $\kappa \mathrm{B}$-induced IFN- $\gamma$ expression [12].

Many studies have shown that IL-27 is an antiviral cytokine important for suppressing HIV-1 in a type I IFNdependent manner [13,14]. For example, IL-27 induces type I IFNs which then upregulate apolipoprotein B mRNAediting catalytic polypeptide-like (APOBEC) cytidine deaminases in macrophages and $\mathrm{CD}^{+} \mathrm{T}$ cells, which interferes with correct genome replication [13]. In line with these reports, numerous studies by Guzzo et al. have demonstrated an impact of HIV infection on IL-27 function, including altered IL-27-induced gene expression in HIV-infected patients [21], and reduced serum IL-27 in patients with high viral loads [22]. indicating that HIV-1 may inhibit IL-27 function. In terms of direct anti-HIV activity, Guzzo et al. showed that IL-27 can induce the expression of tetherin (BST-2), a key host restriction factor implicated in tethering viral particles to the cell surface and limiting virus infection [23].

HIV-1 infection is positively correlated with IL-10 levels in the plasma and blocking IL-10 signalling with an IL-10R $\alpha$-blocking antibody leads to increased HIV-specific 
UNDERGRADUATE RESEARCH IN NATURAL AND CLINICAL SCIENCE AND TECHNOLOGY (URNCST) JOURNAL Read more URNCST Journal articles and submit your own today at: https://www.urncst.com

$\mathrm{CD}^{+} \quad \mathrm{T}$ cell proliferation in untreated infected individuals [24-26]. Interestingly, Kwon et al. demonstrated that $\mathrm{CD} 25^{+} \mathrm{CD} 4^{+}$regulatory $\mathrm{T}$ cells can induce $\mathrm{IL}-10$ expression from monocytes through a paracrine or contactdependent manner [24]. Thus, the crosstalk of regulatory T cells and monocyte-derived IL-10 signalling may represent a potential HIV-1 control mechanism.

Furthermore, IFN- $\alpha$ has important antiviral functions in the early stage of HIV-1 infection. Initially, IFN- $\alpha$ has an antiviral role through the upregulation of interferon stimulated genes (ISGs) that function to reduce HIV-1 replication [27-31]. However, as viruses persist into the chronic phase they become resistant to IFN- $\alpha$ [27]; during chronic HIV-1 infection viral load decreases, less IFN- $\alpha$ is induced, and consequently, the interferon activity becomes neglible [27].

\section{Cytokines that Interact with Innate Immune Cells}

There are several cytokines that combat HIV-1 infection by means of altering or interacting with cells of the innate immune system. Lum et al. studied the roles of IL-7 and IL-15 in boosting the function of NK cells, which in turn can inhibit HIV-1 replication [15]. IL-7-treated NK cells of both HIV-infected and non-infected individuals resulted in increased target cell death via NK cell activity compared to the control (no cytokine treatment) [15]. IL-7 increases expression of Fas ligand in NK cells [15]. which binds Fas (CD95) on $\mathrm{CD}^{+} \mathrm{T}$ cells and induces apoptosis [32]. IL-15treated NK cells of HIV-infected and non-infected individuals also showed enhanced target cell death [15]. IL-15 increases expression of the tumor necrosis factor related apoptosis-inducing ligand (TRAIL) [15]. TRAIL is a cytokine that induces apoptosis upon binding to its receptor [33]. This study also demonstrated that IL-15-stimulated NK cells lead to undetectable levels of HIV p24 in vitro, while IL-7-stimulated NK cells lead to lowered HIV p24, but not to undetectable levels [15]. Overall, this work demonstrates the potential of IL-7 and IL-15 to stimulate antiviral activity from innate immune cells.

Dai et al. showed that IL-27 has an essential function in macrophage resistance to HIV-1 infection [16]. Indeed, IL-27 can downregulate Spectrin $\beta$ noneyrthrocyte 1 (SBTBN1), a necessary component for HIV-1 infection of macrophages. Thus, IL-27 reduces macrophage susceptibility to HIV-1 infection by targeting SBTBN1 [16]. Moreover, Cassol et al. investigated how the differentiation of monocytes to macrophages (classical- M1 or alternatively-activated M2) affects susceptibility to
R5-tropic HIV-1 [34]. HIV-1 replication was reduced in both the M1 and M2 macrophages compared to their monocyte counterparts, however the suppression was most prevalent in the M1 polarized macrophages [34]. Both M1 and M2 macrophages exhibited downregulated cell surface expression of CD4 and CXCR4 receptors, but not CCR5 [17]. Although CCR5 was not decreased on the cell surface, the C-C motif chemokine receptor ligands CCL3 and CCL4 were elevated in M1 and M2, and CCL5 was particularly elevated in the M1 macrophages [34]. The increased expression of these CC ligands is significant because they can bind CCR5 and block subsequent infection. These studies exemplify how cytokines can play key roles in HIV-1 control via direct effects on innate immune cells such as NK cells and macrophages.

\section{Characteristic Cytokines in Elite Controllers}

Elite controllers (ECs), individuals who can naturally suppress HIV-1 infection without therapeutic intervention, express a characteristic array of cytokines that are involved in innate HIV-1 control [18]. Jacobs et al. studied 87 cytokines with the goal of determining the differential cytokine expression levels between ECs and non-controllers [18]. This study consisted of several sample groups: 48 uninfected individuals, 42 non-controllers (>2000 copies HIV-1 RNA/mL), 42 individuals treated with anti-retroviral therapy ( $<80$ copies HIV-1 RNA/mL), and 73 ECs $(<80$ copies HIV-1 RNA/mL) [18]. Jacobs et al. identified that CCL14 and CCL27 exhibited increased expression levels in the ECs in comparison to the uninfected group and the anti-retroviral therapy treated group. 18 Interestingly, these cytokines were not elevated in the noncontrollers, suggesting that they are likely implicated in HIV-1 control [18]. CCL21 was expressed significantly more in ECs in comparison to both non-controllers and uninfected individuals, as well as increased levels in the antiretroviral therapy group compared to non-controllers [18]. Furthermore, XCL1 (lymphotactin), an antiviral chemokine employing a unique mechanism of direct binding to the HIV-1 envelope [35], was also highlighted by Jacobs et al [18]. ECs expressed increased levels of XCL1 in comparison to the anti-retroviral therapy treated group [18]. Lastly, CXCL12 (SDF-1), the natural ligand of the CXCR4 co-receptor [36] with anti-HIV activity [6,37], was elevated in all infected groups, and was particularly elevated in ECs compared to non-controllers [18]. In summary, Jacobs et al. characterized 5 key chemokines, CCL14, CCL27, CCL21, XCL1 and CXCL12, with unique mechanisms through 
UNDERGRADUATE RESEARCH IN NATURAL AND CLINICAL SCIENCE AND TECHNOLOGY (URNCST) JOURNAL Read more URNCST Journal articles and submit your own today at: https://www.urncst.com

which they enhance the ability of ECs to naturally block HIV-1 replication without exogenous therapeutic treatment.

Viremic controllers (VCs) differ from ECs in that they have detectable HIV-1 RNA, while in ECs the HIV-1 RNA levels are undetectable [38,39]. Platten et al. showed that in comparison to VCs, ECs had lower levels of select cytokines, including macrophage inflammatory protein $1 \beta$ (MIP-1 $\beta / C C L 4), \quad$ IFN- $\gamma$-induced protein-10 (IP-10/CXCL10), and monokine induced IFN- $\gamma$ (MIG/CXCL9) [40]. More generally, ECs had lower levels of these cytokines compared to non-controllers [40]. It was also found that $\mathrm{CD} 4^{+} \mathrm{T}$ cell levels decreased over the course of the HIV-1 infection in VCs, but not in ECs [40]. Thus, the work of Platten et al. establishes that ECs have reduced levels of certain cytokines, which may in part explain the lower HIV-1 RNA and more stable $\mathrm{CD}^{+}{ }^{+} \mathrm{T}$ cell levels observed in ECs [40].

IL-21 is a cytokine produced by $\mathrm{CD} 4^{+}$and $\mathrm{CD} 8^{+} \mathrm{T}$ cells, and plays a key role in the effector and memory responses of $\mathrm{CD}^{+} \mathrm{T}$ cells.41 Increased levels of IL-21 results in augmented $\mathrm{CD}^{+} \mathrm{T}$ cell function, differentiation and proliferation, and a greater ability to control HIV-1 replication [41]. Williams et al. investigated the potential role of IL-21 in enhancing the HIV-1 control response in ECs [42]. It was shown that ECs have elevated levels of IL-21-producing $\mathrm{CD} 8^{+} \mathrm{T}$ cells compared to non-controllers [42]. Also, both ECs and VCs had elevated levels of polyfunctional $\mathrm{T}$ cells (cells producing more than one type of cytokine) [42]. This has implications regarding protection against HIV-1 in that the several cytokines produced by a single T cell could enhance the HIV-1 control response [42].

In summary, several studies have established that elite controllers express a unique array of cytokines and chemokines which help control HIV-1 infection more effectively; these cytokines provide insight regarding novel therapeutic targets.

\section{Therapeutic Applications of Cytokines}

It is evident that there is a multitude of cytokines involved in HIV-1 pathogenesis and control of replication. Whether these cytokines impact disease progression in general or directly inhibit virus replication, there are many potential therapeutic applications of cytokines involved in HIV-1.
Interleukin-2 (IL-2) and granulocyte-macrophage colony-stimulating factor (GM-CSF) demonstrate an interesting example of the applications of cytokines in a therapeutic vaccine design. In 2014, Herasimtschuk et al. administered IL-2, GM-CSF, recombinant human growth hormone (rhGH) in combination with DNA Clade B vaccine in HIV-1 infected individuals taking combination antiretroviral therapy (cART) [43]. Importantly, it was observed that the combined treatment of the vaccine, cytokines and rhGH resulted in the highest counts of $\mathrm{CD}^{+}$ and $\mathrm{CD}^{+} \mathrm{T}$ cells compared to receiving only cytokines and growth hormone, or only the vaccine alone [43].

CCR5, one of two essential co-receptors for HIV-1 entry, is a key therapeutic target for therapeutic antagonists.5 RANTES, MIP- $1 \alpha$ and MIP-1 $\beta$, which are HIV-1 suppressive factors secreted by $\mathrm{CD} 8^{+}$cells, were identified to be antagonists of the CCR5 receptor in a landmark study [44]. Interestingly, the activity of RANTES has been targeted in the iterative development of an antiviral drug class aimed at inhibiting HIV entry. Analogs of RANTES have been produced to increase its efficacy as a CCR5 antagonist, however some of these analogs retained downstream signaling resulting in the adverse effect of inducing HIV-1 replication [45-47]. More recently, maraviroc, a synthetic analog, was developed through highthroughput screening as a potent CCR5 antagonist and has started to be included in combination antiretroviral therapies [48]. Maraviroc also inhibits chemokine-induced downstream signaling, and as such it is not an agonist of CCR5 [48].

It has been previously demonstrated that humans and chimpanzees have decreased CD8 responses in HIV-1 infection $[49,50]$. This phenomenon was also demonstrated in macaques infected with the monkey equivalent of HIV, simian immunodeficiency virus (SIV) [51]. However, a series of promising studies showed that IL-12-treated PBMCs can elicit enhanced CD8 responses [52-54], and that IL-12-treated macaques also benefit from restored NK cell counts and activity which are normally decreased post-SIV infection [55].

Taken together, whether it is through direct administration, synthetic analogs, or DNA vaccines, cytokines exhibit diverse roles during HIV-1 infection and bear potential as highly effective therapeutic targets and strategies (Table 1). 
UNDERGRADUATE RESEARCH IN NATURAL AND CLINICAL SCIENCE AND TECHNOLOGY (URNCST) JOURNAL

Read more URNCST Journal articles and submit your own today at: https://www.urncst.com

Table 1: Summary of cytokines in HIV-1 pathogenesis, control, and therapy

\begin{tabular}{|c|c|c|c|c|}
\hline Cytokine & Role(s) in HIV-1 Infection & $\begin{array}{l}\text { Expression in } \\
\text { Elite } \\
\text { Controllers } \\
\end{array}$ & $\begin{array}{l}\text { Therapeutic } \\
\text { Applications }\end{array}$ & References \\
\hline CCL14 & $\begin{array}{l}\text { - Elevated in ECs compared to uninfected } \\
\text { group; not elevated in NCs }\end{array}$ & Elevated & NR. & [18] \\
\hline CCL21 & $\begin{array}{l}\text { - Elevated in ECs compared to uninfected } \\
\text { group and NCs }\end{array}$ & Elevated & NR. & {$[18]$} \\
\hline CCL27 & $\begin{array}{l}\text { - Elevated in ECs compared to uninfected } \\
\text { group; not elevated in NCs }\end{array}$ & Elevated & NR. & [18] \\
\hline CXCL12 (SDF-1) & $\begin{array}{l}\text { - Elevated in all HIV-infected groups } \\
\text { compared to uninfected; elevated in ECs } \\
\text { compared to NCs; anti-HIV activity }\end{array}$ & Elevated & NR. & {$[18,37]$} \\
\hline IFN- $\alpha$ & - Antiviral in early stage of HIV-1 infection & NR. & NR. & [27-31] \\
\hline IFN- $\gamma$ & - Decreases HIV-1 replication & NR. & NR. & {$[12,20]$} \\
\hline IL-10 & $\begin{array}{l}\text { - IL-10 levels positively correlated with } \\
\text { HIV-1 infection }\end{array}$ & NR. & NR. & [24-26] \\
\hline IL-12 & $\begin{array}{l}\text { - Enhances CD8 responses } \\
\text { - Restores NK cell activity in SIV-infected } \\
\text { macaques }\end{array}$ & NR. & $\begin{array}{l}\text { - IL-12 treatment } \\
\text { for enhancing } \\
\text { cellular immunity }\end{array}$ & {$[52-55]$} \\
\hline IL-15 & - IL-15-stimulated NK cells decrease viral load & NR. & NR. & [15] \\
\hline IL-2, GM-CSF & $\begin{array}{l}\text { - Administered with vaccine resulting in } \\
\text { increased } \mathrm{CD} 4^{+} \text {and } \mathrm{CD} 8^{+} \mathrm{T} \text { cell counts }\end{array}$ & NR. & - Vaccine designs & [43] \\
\hline IL-21 & $\begin{array}{l}\text { - Suppresses HIV-1 replication and decreases } \\
\text { viral load } \\
\text { - Elevated levels of IL-21-producing } \mathrm{CD}^{+} \mathrm{T} \\
\text { cells in ECs in comparison to NCs }\end{array}$ & Elevated & NR. & {$[11,42]$} \\
\hline IL-27 & $\begin{array}{l}\text { - Decreases viral load } \\
\text { - Reduces macrophage susceptibility to } \\
\text { HIV-1 infection }\end{array}$ & NR. & NR. & $\begin{array}{l}{[13-14,16,} \\
22-23]\end{array}$ \\
\hline IL-32 & - Inhibits HIV-1 replication & NR. & NR. & {$[12,19]$} \\
\hline IL-7 & - IL-7-stimulated NK cells decrease viral load & NR. & NR. & {$[15]$} \\
\hline IP-10 (CXCL10) & $\begin{array}{l}\text { - Lowered levels in ECs in comparison to } \\
\text { VCs and NCs }\end{array}$ & Reduced & NR. & [40] \\
\hline MIG (CXCL9) & $\begin{array}{l}\text { - Lowered levels in ECs in comparison to } \\
\text { VCs and NCs }\end{array}$ & Reduced & NR. & [40] \\
\hline MIP-1 $\alpha$ (CCL3) & - HIV-1 suppressive factor & NR. & $\begin{array}{l}\text { - CCR5 therapeutic } \\
\text { antagonist }\end{array}$ & [44] \\
\hline MIP-1 $\beta$ (CCL4) & $\begin{array}{l}\text { - Lowered levels in ECs in comparison to } \\
\text { VCs and NCs } \\
\text { - HIV-1 suppressive factor }\end{array}$ & Reduced & $\begin{array}{l}\text { - CCR5 therapeutic } \\
\text { antagonist }\end{array}$ & {$[40,44]$} \\
\hline $\begin{array}{l}\text { RANTES } \\
\text { (CCL5) }\end{array}$ & - HIV-1 suppressive factor & NR. & $\begin{array}{l}\text { - CCR5 therapeutic } \\
\text { antagonist } \\
\text { - Antiviral drug }\end{array}$ & [44] \\
\hline $\begin{array}{l}\text { XCL1 } \\
\text { (lymphotactin) }\end{array}$ & $\begin{array}{l}\text { - Elevated in ECs compared to ART-treated } \\
\text { individuals; antiviral chemokine }\end{array}$ & Elevated & NR. & {$[18,35]$} \\
\hline
\end{tabular}

NR: Not reported within this review

ECs: Elite controllers

NCs: Non-controllers

ART: Anti-retroviral therapy

VCs: Viremic controllers 
UNDERGRADUATE RESEARCH IN NATURAL AND CLINICAL SCIENCE AND TECHNOLOGY (URNCST) JOURNAL Read more URNCST Journal articles and submit your own today at: https://www.urncst.com

\section{Discussion}

Herein we have investigated the roles of several major cytokines and chemokines in HIV-1 pathogenesis and replication control. To date, there has been extensive research covering the antiviral roles of cytokines and their mechanisms of action. This fundamental knowledge is crucial to better understand the virus pathology and potential for new therapeutic designs. Despite this optimism, the intricate system of cytokines and their cross-talk during infections are major hurdles in precisely delineating cytokine potential in therapeutic targets and pathways.

In this review, we have discussed many chemokines that are prevalent in ECs in comparison to HIV-infected noncontrollers. Jacobs et al. showed that CCL14, CCL27, CCL21, XCL1 and CXCL12 are upregulated in ECs compared to non-controllers [18]. However, Jacobs et al. is one of the few studies to have demonstrated differences in ECs and non-controllers. For example, Nunnari et al. did indeed study selected cytokines (IL-18, IFN- $\gamma$ and IL-1 $\beta$ ) in ECs, however they did not find any significant differences in ECs compared to non-controllers [56]. Nonetheless, this study demonstrates that cytokine expression in ECs largely overlaps with non-controllers, and it is likely that the few cytokines that differ (along with several other mechanisms in ECs) are those supporting the innate capacity to control HIV-1 infection. Further research identifying additional antiviral cytokines that are characteristic in ECs will be critically helpful to inform therapeutic strategies.

The field of cytokines in immune infections like HIV-1 holds great potential for the development of novel therapies. However, additional detailed mechanistic studies are warranted to inform the most optimal cytokines to target. It is essential to not only study the antiviral activity of cytokines, but also cytokines that contribute greatly to immune activation and disease progression. One promising method of modulating cytokine activity is with cytokine-specific antibodies, which can be used as treatments to target and neutralize potent cytokines involved in HIV-1 infection. Kwon et al. demonstrated that blocking IL-10 signalling results in increased $\mathrm{CD}^{+}{ }^{+} \mathrm{T}$ cell proliferation in untreated HIV-1 infected individuals [24]. Thus, an anti-IL-10 antibody could potentially be used in conjunction with other neutralizing antibodies targeting cytokines.

On the other hand, the synergistic functions of cytokines can be exploited via administration of cytokine cocktails, with formulations specific to disease states or individual pathogenesis. Taking into account the stage of disease progression, the deficient cytokine levels and various other factors, a cytokine cocktail can be administered in a case-by-case manner so as to meet the needs of each individual patient. For instance, given the supporting data that IL-27, CCL14, CCL27, CCL21, XCL1 and CXCL12 can inhibit HIV-1 infection [16,18], one could surmise that benefit of developing an optimized combination of these cytokines to maximize HIV inhibition and limit adverse immune effects. However, any given blend of cytokines would require extensive study to determine effectiveness, safety, and suitability to individual patients.

\section{Conclusions}

Taken together, this review highlighted the roles of several cytokines during HIV-1 pathogenesis and host control mechanisms. It is evident that many cytokines play a key role during infection and exploiting them may inform novel therapeutic targets. It remains crucially imperative to continue mechanistic studies that investigate the effectiveness of cytokine therapies, critically analyze the potential for resistance mechanisms, and minimize off-target activities that may have toxicity in patients. Moving forward, this field has great potential to unravel highly effective therapeutic methods in order to treat or prevent HIV-1 infection.

\section{List of Abbreviations}

HIV: Human Immunodeficiency Virus

gp: Glycoprotein

IL: Interleukin

NK: Natural Killer

EC: Elite Controller

PBMC: Peripheral Blood Mononuclear Cells

IFN: Interferon

TNF: Tumor Necrosis Factor

ISG: Interferon Stimulated Gene

SBTBN1: Spectrin B Nonerythrocyte 1

MIP: Macrophage Inflammatory Protein

IP-10: IFN- $\gamma$-Induced Protein-10

MIG: Monokine Induced IFN- $\gamma$

GM-CSF: Granulocyte-Macrophage Colony-Stimulating

Factor

rhGH: Recombinant Human Growth Hormone

cART: Combination Antiretroviral Therapy

SIV: Simian Immunodeficiency Virus

CCR5: C-C chemokine receptor type 5

CXCR4: C-X-C chemokine receptor type 4

CCL: C-C motif chemokine ligand

\section{Conflicts of Interest}

The authors declare that they have no conflict of interests.

\section{Ethics Approval and/or Participant Consent}

This study did not require ethics approval and/or participant consent as it is a literature review.

\section{Authors' Contributions}

$\mathrm{HH}$ : made substantial contributions to the conception and design of the work, conducted literature review, analysis and interpretation, drafted the manuscript, and gave final approval of the version to be published. 
UNDERGRADUATE RESEARCH IN NATURAL AND CLINICAL SCIENCE AND TECHNOLOGY (URNCST) JOURNAL Read more URNCST Journal articles and submit your own today at: https://www.urncst.com

CG: made substantial contributions to the conception and design of the work, assisted with analysis and interpretation, revised the manuscript critically, and gave final approval of the version to be published.

\section{Acknowledgements}

This manuscript was initially drafted with guidance from Dr. Aarthi Ashok at the University of Toronto Scarborough. $\mathrm{HH}$ was the recipient of the Research Abstract Competition Award, subsequently providing the opportunity to submit this work in its entirety herein.

\section{Funding}

This study was not funded.

\section{References}

[1] World Health Organization. HIV/AIDS. http://www.who.int/en/news-room/factsheets/detail/hiv-aids

[2] Turner BG, Summers MF. Structural biology of HIV. J Mol Biol. 1999;285(1):1-32.

https://doi.org/10.1006/jmbi.1998.2354

[3] Sharp PM, Hahn BH. Origins of HIV and the AIDS Pandemic. Cold Spring Harb Perspect Med. 2011;1(1):a006841. http://doi:10.1101/cshperspect.a006841

[4] Pancera M, Majeed S, Ban Y-EA, Chen L, Huang C -c., Kong L, et al. Structure of HIV-1 gp120 with gp41-interactive region reveals layered envelope architecture and basis of conformational mobility. Proc Natl Acad Sci. 2010;107(3):1166-71 https://doi.org/10.1073/pnas.0911004107

[5] Blumenthal R, Durell S, Viard M. HIV entry and envelope glycoprotein-mediated fusion. J Biol Chem. 2012;287(49):40841-9. http://doi.org/10.1074/jbc.R112.406272

[6] Bleul CC, Wu L, Hoxie JA, Springer TA, Mackay CR. The HIV coreceptors CXCR4 and CCR5 are differentially expressed and regulated on human T lymphocytes. Proc Natl Acad Sci. 1997;94(5): 1925-30. https://doi.org/10.1073/pnas.94.5.1925

[7] $\mathrm{Hu}$ W-S, Hughes SH. HIV-1 reverse transcription. Cold Spring Harb Perspect Med. 2012;a006882. http://doi.org/10.1101/cshperspect.a006882

[8] Doitsh G, Galloway NLK, Geng X, Yang Z, Monroe KM, Zepeda O, et al. Cell death by pyroptosis drives CD4 T-cell depletion in HIV-1 infection. Nature. 2014;505(7484):509-14. http://dx.doi.org/10.1038/nature12940

[9] Dinarello CA. Historical insights into cytokines. Eur J Immunol. 2007;37(SUPPL. 1):S34-45. https://doi.org/10.1002/eji.200737772

[10] Kedzierska K, Crowe SM. Cytokines and HIV-1: Interactions and clinical implications. Antivir Chem Chemother. 2001;12(3):133-50. https://doi.org/10.1177/095632020101200301

[11] Adoro S, Cubillos-Ruiz JR, Chen X, Deruaz M, Vrbanac VD, Song M, et al. IL-21 induces antiviral
microRNA-29 in CD4 T cells to limit HIV-1 infection. Nat Commun. 2015;6:7562. http://dx.doi.org/10.1038/ncomms8562

[12] Nold MF, Nold-Petry CA, Pott GB, Zepp JA, Saavedra MT, Kim S-H, et al. Endogenous IL-32 Controls Cytokine and HIV-1 Production. J Immunol. 2008;181(1):557-65. https://doi.org/10.4049/jimmunol.181.1.557

[13] Greenwell-Wild T, Vázquez N, Jin W, Rangel Z, Munson PJ, Wahl SM. Interleukin-27 inhibition of HIV-1 involves an intermediate induction of type I interferon. Blood. 2009;114(9):1864-74. https://dx.doi.org/10.1182/blood-2009-03-211540

[14] Imamichi T, Yang J, Huang DW, Brann TW, Fullmer BA, Adelsberger JW, et al. IL-27, a novel anti-HIV cytokine, activates multiple interferon-inducible genes in macrophages. A. 2008;22(1):39-45. http://dx.doi.org/10.1097/QAD.0b013e3282f3356c

[15] Lum JJ, Schnepple DJ, Nie Z, Sanchez-Dardon J, Mbisa GL, Mihowich J, et al. Differential Effects of Interleukin-7 and Interleukin-15 on NK Cell AntiHuman Immunodeficiency Virus Activity. J Virol. 2004;78(11):6033-42. https://doi.org/10.1128/JVI.78.11.6033-6042.2004

[16] Dai L, Lidie KB, Chen Q, Adelsberger JW, Zheng X, Huang D, et al. IL-27 inhibits HIV-1 infection in human macrophages by down-regulating host factor SPTBN1 during monocyte to macrophage differentiation. J Exp Med. 2013; http://doi.org/10.1084/jem.20120572

[17] Cassol E, Cassetta L, Alfano M, Poli G. Macrophage polarization and HIV-1 infection. J Leukoc Biol. 2010; https://doi.org/10.1189/jlb.1009673

[18] Jacobs ES, Keating SM, Abdel-Mohsen M, Gibb SL, Heitman JW, Inglis HC, et al. Cytokines Elevated in HIV Elite Controllers Reduce HIV Replication In Vitro and Modulate HIV Restriction Factor Expression. J Virol. 2017;91(6):e02051-16. https://doi.org/10.1128/JVI.02051-16

[19] Rasool ST, Tang H, Wu J, Li W, Mukhtar MM, Zhang J, et al. Increased level of IL-32 during human immunodeficiency virus infection suppresses HIV replication. Immunol Lett. 2008;117(2):161-7. http://dx.doi.org/10.1016/j.imlet.2008.01.007

[20] Patterson BK, Tjernlund A, Andersson J. Endogenous inhibitors of HIV: potent anti-HIV activity of leukemia inhibitory factor. Curr Mol Med. 2002;2(8):713-22. https://doi.org/10.2174/1566524023361817

[21] Guzzo C, Hopman WM, Che Mat NF, Wobeser W, Gee K. IL-27-Induced Gene Expression Is Downregulated in HIV-Infected Subjects. PLoS One. 2012;7(9):e45706. https://doi.org/10.1371/journal.pone.0045706

[22] Guzzo C, Hopman WM, Mat NFC, Wobeser W, Gee K. Impact of HIV infection, highly active antiretroviral therapy, and hepatitis $\mathrm{C}$ coinfection on serum interleukin-27. AIDS. 2010;24(9):1371-4. http://dx.doi.org/10.1097/QAD.0b013e3283391d2b 
UNDERGRADUATE RESEARCH IN NATURAL AND CLINICAL SCIENCE AND TECHNOLOGY (URNCST) JOURNAL Read more URNCST Journal articles and submit your own today at: https://www.urncst.com

[23] Guzzo C, Jung M, Graveline A, Banfield BW, Gee K. IL-27 increases BST-2 expression in human monocytes and T cells independently of type i IFN. Sci Rep. 2012;2:974. http://dx.doi.org/10.1038/srep00974

[24] Kwon DS, Angin M, Hongo T, Law KM, Johnson J, Porichis F, et al. CD4 ${ }^{+} \mathrm{CD} 25^{+}$Regulatory T Cells Impair HIV-1-Specific CD4 T Cell Responses by Upregulating Interleukin-10 Production in Monocytes. J Virol. 2012;86(12):6586-94. https://doi.org/10.1128/JVI.06251-11

[25] Brockman MA, Kwon DS, Tighe DP, Pavlik DF, Rosato PC, Sela J, et al. IL-10 is up-regulated in multiple cell types during viremic HIV infection and reversibly inhibits virus-specific $\mathrm{T}$ cells. Blood. 2009;114(2):346-356. https://doi:10.1182/blood-2008-12-191296

[26] Stylianou E, Aukrust P, Kvale D, Müller F, FrØland SS. IL-10 in HIV infection: Increasing serum IL-10 levels with disease progression-down-regulatory effect of potent anti-retroviral therapy. Clin Exp Immunol. 1999;116(1):115-120. http://doi:10.1046/j.1365-2249.1999.00865.x

[27] Fenton-May AE, Dibben O, Emmerich T, Ding H, Pfafferott K, Aasa-Chapman MM, et al. Relative resistance of HIV-1 founder viruses to control by interferon-alpha. Retrovirology. 2013;10(1). http://dx.doi.org/10.1186/1742-4690-10-146

[28] Schoggins JW, Wilson SJ, Panis M, Murphy MY, Jones CT, Bieniasz P, et al. A diverse range of gene products are effectors of the type I interferon antiviral response. Nature. 2011;472(7344):481-5. http://dx.doi.org/10.1038/nature09907

[29] Peng G, Ke JL, Jin W, Greenwell-Wild T, Wahl SM. Induction of APOBEC3 family proteins, a defensive maneuver underlying interferon-induced anti-HIV-1 activity. J Cell Biol. 2006;172(3):41-6. http://dx.doi.org/10.1084/jem.20051512

[30] Stremlau M, Owens CM, Perron MJ, Kiessling M, Autissier P, Sodroski J. The cytoplasmic body component TRIM5 $\alpha$ restricts HIV-1 infection in Old World monkeys. Nature. 2004;427(6977):848-53.

[31] Lu J, Pan Q, Rong L, Liu S-L, Liang C. The IFITM Proteins Inhibit HIV-1 Infection. J Virol. 2011;85(5):2126-37. http://dx.doi.org/10.1128/JVI.01531-10

[32] Badley AD, McElhinny JA, Leibson PJ, Lynch DH, Alderson MR, Paya C V. Upregulation of Fas ligand expression by human immunodeficiency virus in human macrophages mediates apoptosis of uninfected T lymphocytes. J Virol. 1996;70(1):199-206.

[33] Mirandola P, Ponti C, Gobbi G, Sponzilli I, Vaccarezza M, Cocco L, et al. Activated human NK and $\mathrm{CD}^{+} \mathrm{T}$ cells express both TNF-related apoptosisinducing ligand (TRAIL) and TRAIL receptors but are resistant to TRAIL-mediated cytotoxicity. Blood.
2004;104(8):2418-24. https://doi.org/10.1182/blood-2004-04-1294

[34] Cassol E, Cassetta L, Rizzi C, Alfano M, Poli G. M1 and M2a Polarization of Human Monocyte-Derived Macrophages Inhibits HIV-1 Replication by Distinct Mechanisms. J Immunol. 2009;182(10):6237-46. http://dx.doi.org/10.4049/jimmunol.0803447

[35] Guzzo C, Fox J, Lin Y, Miao H, Cimbro R, Volkman BF, et al. The CD8-Derived Chemokine XCL1/Lymphotactin Is a Conformation-Dependent, Broad-Spectrum Inhibitor of HIV-1. PLoS Pathog. 2013;9(12):1-11. https://doi.org/10.1371/journal.ppat.1003852

[36] Alkhatib G. The biology of CCR5 and CXCR4. Curr Opin HIV AIDS. 2009;4(2):96-103. http://dx.doi.org/10.1097/COH.0b013e328324bbec

[37] Altenburg JD, Jin Q, Alkhatib B, Alkhatib G. The Potent Anti-HIV Activity of CXCL12 $\gamma$ Correlates with Efficient CXCR4 Binding and Internalization. J Virol. 2010;84(5):2563-72.

[38] Okulicz JF, Marconi VC, Landrum ML, Wegner S, Weintrob A, Ganesan A, et al. Clinical Outcomes of Elite Controllers, Viremic Controllers, and Long-Term Nonprogressors in the US Department of Defense HIV Natural History Study. J Infect Dis. 2009;200(11):1714-23. http://dx.doi.org/10.1086/646609

[39] Grabar S, Selinger-Leneman H, Abgrall S, Pialoux G, Weiss L, Costagliola D. Prevalence and comparative characteristics of long-term nonprogressors and HIV controller patients in the French Hospital Database on HIV. Aids. 2009;23(9):1163-9. http://dx.doi.org/10.1097/QAD.0b013e32832b44c8

[40] Platten M, Jung N, Trapp S, Flossdorf P, Meyer-Olson D, Schulze zur Wiesch J, et al. Cytokine and Chemokine Signature in Elite Versus Viremic Controllers Infected with HIV. AIDS Res Hum Retroviruses. 2016;32(6):579-87. http://dx.doi.org/10.1089/aid.2015.0226

[41] Casey KA, Mescher MF. IL-21 Promotes Differentiation of Naive CD8 T Cells to a Unique Effector Phenotype. J Immunol. 2007;178(12):7640-8. https://doi.org/10.4049/jimmunol.178.12.7640

[42] Williams LD, Bansal A, Sabbaj S, Heath SL, Song W, Tang J, et al. Interleukin-21-Producing HIV-1Specific CD8 T Cells Are Preferentially Seen in Elite Controllers. J Virol. 2011;85(5):2316-24. http://dx.doi.org/10.1128/JVI.01476-10

[43] Herasimtschuk A, Downey J, Nelson M, Moyle G, Mandalia S, Sikut R, et al. Therapeutic immunisation plus cytokine and hormone therapy improves CD4 $\mathrm{T}$-cell counts, restores anti-HIV-1 responses and reduces immune activation in treated chronic HIV-1 infection. Vaccine. 2014;32(51):7005-13. http://dx.doi.org/10.1016/j.vaccine.2014.09.072 
UNDERGRADUATE RESEARCH IN NATURAL AND CLINICAL SCIENCE AND TECHNOLOGY (URNCST) JOURNAL Read more URNCST Journal articles and submit your own today at: https://www.urncst.com

[44] Cocchi F, DeVico AL, Garzino-Demo A, Arya SK, Gallo RC, Lusso P. Identification of RANTES, MIP-1 $\alpha$, and MIP-1 $\beta$ as the major HIV-suppressive factors produced by CD8 ${ }^{+}$T cells. Science. 1995;270(5243):1811.

[45] Proudfoot AEI, Power CA, Hoogewerf AJ, Montjovent MO, Borlat F, Offord RE, et al. Extension of recombinant human RANTES by the retention of the initiating methionine produces a potent antagonist. J Biol Chem. 1996;271(5):2599-603. http://dx.doi.org/10.1074/jbc.271.5.2599

[46] Simmons G, Clapham PR, Picard L, Offord RE, Rosenkilde MM, Schwartz TW, et al. Potent inhibition of HIV-1 infectivity in macrophages and lymphocytes by a novel CCR5 antagonist. Science. 1997;276(5310):276-9. http://dx.doi.org/10.1126/science.276.5310.276

[47] Rodríguez-Frade JM, Vila-Coro AJ, Martín A, Nieto M, Sánchez-Madrid F, Proudfoot AEI, et al. Similarities and differences in RANTES- and (AOP)RANTES-triggered signals: Implications for chemotaxis. J Cell Biol. 1999;144(4):755-65. https://doi.org/10.1083/jcb.144.4.755

[48] Dorr P, Westby M, Dobbs S, Griffin P, Irvine B, Macartney M, et al. Maraviroc (UK-427,857), a potent, orally bioavailable, and selective smallmolecule inhibitor of chemokine receptor CCR5 with broad-spectrum anti-human immunodeficiency virus type 1 activity. Antimicrob Agents Chemother. 2005;49(11):4721-32. https://doi.org/10.1128/AAC.49.11.4721-4732.2005

[49] Chougnet C, Wynn TA, Clerici M, Landay AL, Kessler HA, Rusnak J, et al. Molecular analysis of decreased interleukin-12 production in persons infected with human immunodeficiency virus. J Infect Dis. 1996;174(1):46-53. https://doi.org/10.1093/infdis/174.1.46

[50] Villinger F, Brar SS, Brice GT, Chikkala NF, Novembre FJ, Mayne AE, et al. Immune and hematopoietic parameters in HIV-1-infected chimpanzees during clinical progression toward AIDS. J Med Primatol. 1997;26(1-2):11-8. https://doi.org/10.1111/j.1600-0684.1997.tb00314.X

[51] Dittmer U, Spring M, Petry H, Nisslein T, Rieckmann $\mathrm{P}$, Lüke W, et al. Cell-mediated immune response of macaques immunized with low doses of simian immunodeficiency virus (SIV). J Biotechnol. 1996;44(1-3):105-10. http://dx.doi.org/10.1016/0168-1656(95)00160-3

[52] Clerici M, Lucey DR, Berzofsky JA, Pinto LA, Wynn TA, Blatt SP, et al. Restoration of HIV-specific cell-mediated immune responses by interleukin-12 in vitro. Science. 1993;262(5140):1721-4. http://dx.doi.org/10.1126/science.7903123

[53] Landay AL, Clerici M, Hashcmi F, Kessler H, Berzofsky JA, Shearer GM. In vitro restoration of $\mathrm{T}$ cell immune function in human immunodeficiency virus-positive persons: Effects of interleukin (IL)-12 and anti-IL-10. J Infect Dis. 1996;173(5):1085-91. https://doi.org/10.1093/infdis/173.5.1085

[54] Paganin C, Frank I, Trinchieri G. Priming for high interferon-gamma production induced by interleukin12 in both $\mathrm{CD}^{+}$and $\mathrm{CD}^{+} \mathrm{T}$ cell clones from HIVinfected patients. J Clin Invest. 1993;96(3):1677-82. http://dx.doi.org/10.1172/JCI118209

[55] Villinger F, Bucur S, Chikkala NF, Brar SS, Bostik P, Mayne AE, et al. In vitro and in vivo responses to interleukin 12 are maintained until the late SIV infection stage but lost during AIDS. AIDS Res Hum Retroviruses. 2000;16(8):751-63. https://doi.org/10.1089/088922200308756

[56] Nunnari G, Fagone P, Condorelli F, Nicoletti F, Malaguarnera L, Di Rosa M. CD4 ${ }^{+}$T-cell gene expression of healthy donors, HIV-1 and elite controllers: Immunological chaos. Cytokine. 2016;83:127-35. https://doi.org/10.1016/j.cyto.2016.04.007

\section{Article Information}

Managing Editor: Jeremy Y. Ng

Peer Reviewers: Edna Matta-Camacho, Jennifer Williams

Article Dates: Received Dec 12 18; Accepted May 20 19; Published May 2919

\section{Citation}

Please cite this article as follows:

Hamidzada H, Guzzo C. Pleiotropic roles of cytokines in HIV-1 pathogenesis and control: A literature review. URNCST Journal. 2019 May 29: 3(5). https://urncst.com/index.php/urncst/article/view/128

DOI Link: https://doi.org/10.26685/urncst.128

\section{Copyright}

(C) Homaira Hamidzada, Christina Guzzo (2019). Published first in the Undergraduate Research in Natural and Clinical Science and Technology (URNCST) Journal. This is an open access article distributed under the terms of the Creative Commons Attribution License (https://creativecommons.org/licenses/by/4.0/), which permits unrestricted use, distribution, and reproduction in any medium, provided the original work, first published in the Undergraduate Research in Natural and 
Clinical Science and Technology (URNCST) Journal, is properly cited. The complete bibliographic information, a link to the original publication on http://www.urncst.com, as well as this copyright and license information must be included.

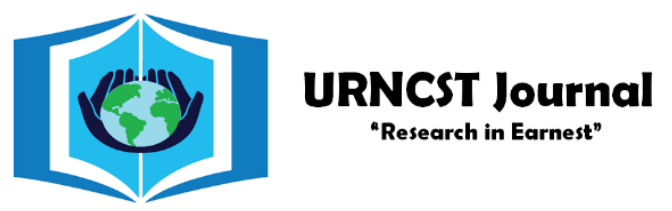

\section{Funded by the Government of Canada}

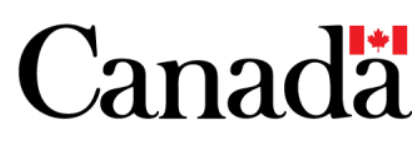

Do you research in earnest? Submit your next undergraduate research article to the URNCST Journal! | Open Access | Peer-Reviewed | Rapid Turnaround Time | International | | Broad and Multidisciplinary | Indexed | Innovative | Social Media Promoted |

Pre-submission inquiries? Send us an email at info@urncst.com | Facebook, Twitter and LinkedIn: @URNCST Submit YOUR manuscript today at https://www.urncst.com! 